\title{
PRODUCTION COST AND MARKET ANALYSIS OF MANDARIN IN DHADING DISTRICT OF NEPAL
}

D. Shrestha ${ }^{1}$

\section{ABSTRACT}

A study was conducted in 2010 to explore the value chain of the mandarin business in two VDCs; Nalang and J ogimara of Dhading district, Nepal. Information were collected through survey from 60 mandarin growers, 4 collectors, 2 agroinput traders, 2 fruit nurseries, 4 technical service providers, 4 dealers, 4 wholesalers, 4 retailers and 20 consumers. Different direct actors and organizations were found to be involved in micro, meso and macro levels of the mandarin value chain. The technical structure of the mandarin value chain was found as the input provision, mandarin production, intermediary trading, retailing, and consumption. The value chain was linked to different regions of the country. On an average, mandarin producers incurred total variable cost of NRs 10.40 per $\mathrm{kg}$ of mandarin. Their gross margin was NRs 8.44 per $\mathrm{kg}$ of mandarin. The cost of marketing of the traders, wholesalers, and retailers were NRs 3.56, 5.38 and 1.98 per $\mathrm{kg}$ of mandarin respectively whereas the margins of each of them were NRs 2.54, 2.36 and 5.01 per $\mathrm{kg}$ of mandarin respectively. The role of traders was found dominant in both purchasing of mandarin from producers and supplying to other districts. The majority of producers were not getting adequate training, support and supervision from concerned organizations. The major weakness in mandarin value chain was unorganized marketing system. Intermediaries and retailers were always found to be in profit. Therefore, the concerned organizations should bring policies in fixing the market price of mandarin based on cost of production. An upgrading strategy with the technology based processed mandarin production has a great opportunity to enter in the new value chain for further improvements in the existing mandarin business.

Key words: Mandarin, marketing, value chain

\section{INTRODUCTION}

Nepal has been a predominantly agrarian economy since time immemorial. The development efforts over the last few decades have doubtlessly strengthened our industrial base. However, agriculture continues to be the mainstay of our economy and even today 65.6 per cent of population depends on it (CBS, 2010).

Mandarin contributes to augmenting food availability, improvements in nutrition, generation of employment and income and also helps in maintaining the environment (Shah, 1992; Gurung, 1993; Shrestha et al., 1998; Tomiyashu et al., 1998). The total area under cultivation, productive area and production of citrus in Nepal during 2013/14 were $38,988 \mathrm{ha}, 25,497$ ha and 2,24,357 mt, respectively. Similarly, the total area under cultivation, productive area and production of mandarin in Nepal are 25,408 ha, 16,528 ha and 1, 49,316 mt, respectively. The area under mandarin is 65.16 per cent of the citrus

\footnotetext{
${ }^{1}$ Planning Officer, Kisanka lagi Unnat Biu-bijan Karyakram (KUBK), Nepal
}

$-112-$ 
fruits and 26.3 per cent of the total area covered by fruits in the country. Citrus, particularly the mandarin is the most important commercial fruit crop in the hills of Nepal. Dhading is one of the potential district for mandarin production in the mid hills of Nepal with 509 ha area under mandarin cultivation with a production area of 305 ha and production of 3,050 $\mathrm{mt}$ (ABPSD, 2014).

Although Dhading district has a number of mandarin production pockets in Nepal, the productivity has not increased significantly over the years as per the expectations of Agriculture Perspective Plan (APP) due to several technological constraints. For example inadequate information on pricing mechanism and poor knowledge on linkages along the chain, farmers are receiving lower price for mandarin fruits while middleman are taking the highest proportion of share. As a result farmers are unwilling to invest more in the mandarin cultivation. Inadequate knowledge of value chain and inefficient product flow and market information, producers are always suffering from poor share of profit from the business.

Hence, this study was conducted to explore production cost and market analysis of mandarin in Dhading district, Nepal.

\section{MATERIALS AND METHODS}

Nalang and Jogimara VDCs of Dhading district were purposively selected for this study based on the area coverage, production, number of growers and access to road facilities. As a whole, 60 respondents comprising 30 mandarin growers from each VDC, were selected randomly. During the study, 4 collectors, 2 agroinput traders , 4 technical service providers, 4 traders, 4 wholesalers, 4 retailers and 20 consumers from Dhading district and 2 citrus nurseries from Gorkha district were selected for getting information on marketing and value chain study randomly. Pre-tested interview schedule was used to collect the primary data from the selected farmers applying face-to-face interview method. Focus group discussions and key informants survey were done to collect the relevant information. At final phase, group interaction with key informants including all stakeholders of value chain was conducted for the validation of data collected. The secondary data were obtained through reviewing publications of concerned institutions. The data obtained from the field were analyzed through SPSS and MS-EXCEL and interpreted.

\section{RESULTS AND DISCUSSION}

\section{COST OF PRODUCTION OF MANDARIN}

The production of mandarin depends on the levels of inputs used like manure, fertilizer, human labor, chemicals and irrigation. Table 1 represents the VDC wise cost of production 
and return from mandarin in Dhading district. The average cost of production per hectare was NRs 140.34. The cost of production per hectare was higher in Nalang VDC (NRs 141.97) compared to Jogimara (NRs 138.70). The benefit cost ratio analysis showed that the mandarin cultivation was profitable enterprise with the $\mathrm{B} / \mathrm{C}$ ratio greater than one i.e. 3.32 for Nalang and 2.73 for Jogimara VDC. This finding was also supported by Gupta and George (1974) as they found $B / C$ ratio ranging from 1.85 to 2.64 in Indian condition depending on the size of orchard. The benefit cost ratio was higher in Nalang VDC. The higher cost of production and return in Nalang VDC might be due to the higher amount of inputs (ie manure and fertilizers) used for producing the mandarin orange than Jogimara VDC. The slightly higher benefit cost ratio might be due to only consideration of variable cost while calculating cost of production.

Table 1. VDC wise cost of production and return from mandarin orange in Dhading district, 2010

\begin{tabular}{llll}
\multicolumn{1}{c}{ VDC } & Cost (Rs/hectare) & Return (Rs/ hectare) & B/C ratio \\
\hline Nalang & 141.97 & 471.35 & 3.32 \\
Jogimara & 138.70 & 378.65 & 2.73 \\
\hline Total & 280.67 & 850.00 & 3.02 \\
\hline
\end{tabular}

Analysis of contribution of variable cost items to the total cost

The Ordinary Least Squares (OLS) estimates of the contribution of variable cost items to the total cost of mandarin production in Nalang and Jogimara VDCs in Dhading district are presented in the table 2 and 3.

Table 2. Contribution of variable cost items to the total cost in Nalang VDC, Dhading, 2010

\begin{tabular}{|c|c|c|c|c|c|}
\hline \multirow[t]{2}{*}{ Variables } & \multicolumn{2}{|c|}{$\begin{array}{l}\text { Unstandardized } \\
\text { coefficients }\end{array}$} & \multirow{2}{*}{$\begin{array}{c}\text { Standardized } \\
\text { coefficients } \\
\text { Beta }\end{array}$} & \multirow[t]{2}{*}{$\mathrm{T}$} & \multirow[t]{2}{*}{$P$ value } \\
\hline & B & SE & & & \\
\hline Constant & 838.12 & 234.86 & & 3.57 & 0.001 \\
\hline Manuring and fertilizer cost & 1.42 & 0.19 & 0.76 & 7.30 & $0.000^{* *}$ \\
\hline Plant protection cost & 2.96 & 1.47 & 0.21 & 2.02 & $0.054^{*}$ \\
\hline Irrigation cost & 3.75 & 2.42 & 0.13 & 1.55 & 0.133 \\
\hline
\end{tabular}

Dependent Variable: Total cost, $\mathrm{SE}=$ Standard Error. Note: ** and * refers to significant at 0.01 and 0.10 level of significance, respectively.

Manuring and fertilizer cost and plant protection cost had strong statistical significant factors contributing to the total cost. Both manuring and fertilizer cost and plant protection cost had positive contribution to the total cost. The irrigation cost was found insignificant in contribution to the total cost but it contributed positively to the total cost. 
The value of multiple coefficient of correlation, $\mathrm{R}$, was found to be 0.899 which indicates the strong correlation between dependent and independent variables in the analysis. This indicates that 89.9 per cent variation in dependent variable was explained by all independent variables.

Table 3. Contribution of variable cost items to the total cost in Jogimara VDC in Dhading district, 2010

\begin{tabular}{|c|c|c|c|c|c|}
\hline \multirow[t]{2}{*}{ Variables } & \multicolumn{2}{|c|}{$\begin{array}{l}\text { Unstandardized } \\
\text { coefficients }\end{array}$} & \multirow{2}{*}{$\begin{array}{c}\text { Standardized } \\
\text { coefficients } \\
\text { Beta }\end{array}$} & \multirow[t]{2}{*}{$\mathrm{T}$} & \multirow[t]{2}{*}{$P$ value } \\
\hline & B & SE & & & \\
\hline Constant & 1410.68 & 281.55 & & 5.010 & 0.000 \\
\hline Manuring and fertilizer cost & 1.03 & 0.21 & 0.694 & 4.835 & $0.000^{* *}$ \\
\hline Plant protection cost & 0.57 & 1.52 & 0.690 & 0.374 & 0.712 \\
\hline Irrigation cost & 1.66 & 2.1 & 0.144 & 0.769 & 0.449 \\
\hline
\end{tabular}

$\mathrm{R}=0.697, \mathrm{R}^{2}=0.486$, Dependent Variable: Total cost, $\mathrm{SE}=$ Standard Error.

Note: ** refers to significant at 0.01 level of significance.

Manuring and fertilizer cost had strong statistical significant factors contributing to the total cost. Manuring and fertilizer cost had positive contribution to the total cost. The plant protection cost and irrigation cost were found insignificant in contribution to the total cost but both the costs contributed positively to the total cost. The value of multiple coefficient of correlation, $\mathrm{R}$, was found to be 0.697 which indicates the strong correlation between dependent and independent variables in the analysis. This indicates that 69.7 per cent variation in dependent variable was explained by all independent variables.

\section{REVENUE AND GROSS MARGIN}

The average revenue per hectare and per $\mathrm{kg}$ of mandarin is presented in the Table 4 . The average revenue per hectare was NRs. 425 whereas the average revenue per kg was NRs 13 from the mandarin production. Among the two VDCs, the producers of Nalang VDC were getting the higher revenue from both per hectare and per kg basis which were NRs 471 and NRs 14 respectively. This might be due to the better management practices adopted by the producers of Nalang VDC.

Table 4. Average revenue from mandarin production by VDC in Dhading district, 2010

\begin{tabular}{llll}
\hline \multicolumn{1}{c}{ Revenue (NRs) } & & Nalang & \multicolumn{2}{c}{ VDCs } & Average revenue \\
\hline Per hectare & 471 & 379 & 425 \\
Per kg & 14 & 11 & 13 \\
\hline
\end{tabular}

Table 5 shows the average gross margin per hectare and per $\mathrm{kg}$ from mandarin production by VDC.

Table 5. Average gross margin from mandarin production by VDC in Dhading district, 2010 


\begin{tabular}{lllll}
\hline \multicolumn{1}{c}{ Gross margin (NRs) } & Nalang & VDCs & Jogimara & Average gross margin \\
\hline Per hectare & 329 & 240 & 285 \\
Per kg & 10 & 7 & 8 \\
\hline
\end{tabular}

The average gross margin from the mandarin production was NRs 285 per hectare and NRs 8 per kg of mandarin. In comparision, Nalang VDC captured the higher gross margin in both per hectare and per $\mathrm{kg}$ of mandarin as compared to Jogimara VDC. It may due to the reason that most of the mandarin growers from Nalang sell their produce directly to the retail markets.

\section{PRICE OF MANDARIN FRUIT}

For the marketing of the mandarin, the activities start right from the point of the production. In the context of mandarin marketing activities in Dhading district, the intermediaries and the retailers were found to play major role. Similarly, the retailers also had direct access to the mandarin producers for the exchange function. The distribution of mandarin producers by place of selling and VDC is presented in the Table 6 .

Table 6. Distribution of mandarin producers by place of selling and VDC

\begin{tabular}{|c|c|c|c|}
\hline \multirow{2}{*}{ Place of selling } & \multicolumn{2}{|c|}{ VDCs } & \multirow{2}{*}{ Total } \\
\hline & Nalang & Jogimara & \\
\hline Farm gate & $20(66.67)$ & $16(53.33)$ & $36(60.00)$ \\
\hline Market & $4(13.33)$ & $2(6.67)$ & $6(10.00)$ \\
\hline Farm gate + Market & $6(20.00)$ & $12(40.00)$ & $18(30.00)$ \\
\hline Total & $30(100.00)$ & $30(100.00)$ & $60(100.00)$ \\
\hline
\end{tabular}

The majority of the mandarin producers $(60 \%)$ sold their produce at farm gate where as only few producers $(10 \%)$ sold their produce directly to the market. It was found that 30 per cent producers sold part of the production in the market and remaining part from the farm gate. In both the VDCs, most of the farmers were engaged selling the produce from the farm gate and few farmers were selling directly to the market.

\section{QUANTITY OF MANDARIN SUPPLY}

Figure 1 illustrates the volume mapping of mandarin supply in Dhading district. It was found that the the intermediaries were the major agents for the transaction of mandarin to consumers outside Dhading district. From the discussions with the value chain actors of Dhading district, it was found that 88 per cent of the total produce i.e. 3,030 metric ton was consumed by the local consumers. Only 12 per cent of the remaining produce was 
transacted to other districts namely Kathmandu, Pokhara, Narayangadh, and Birgunj including some negligible volume to India from the intermediaries.
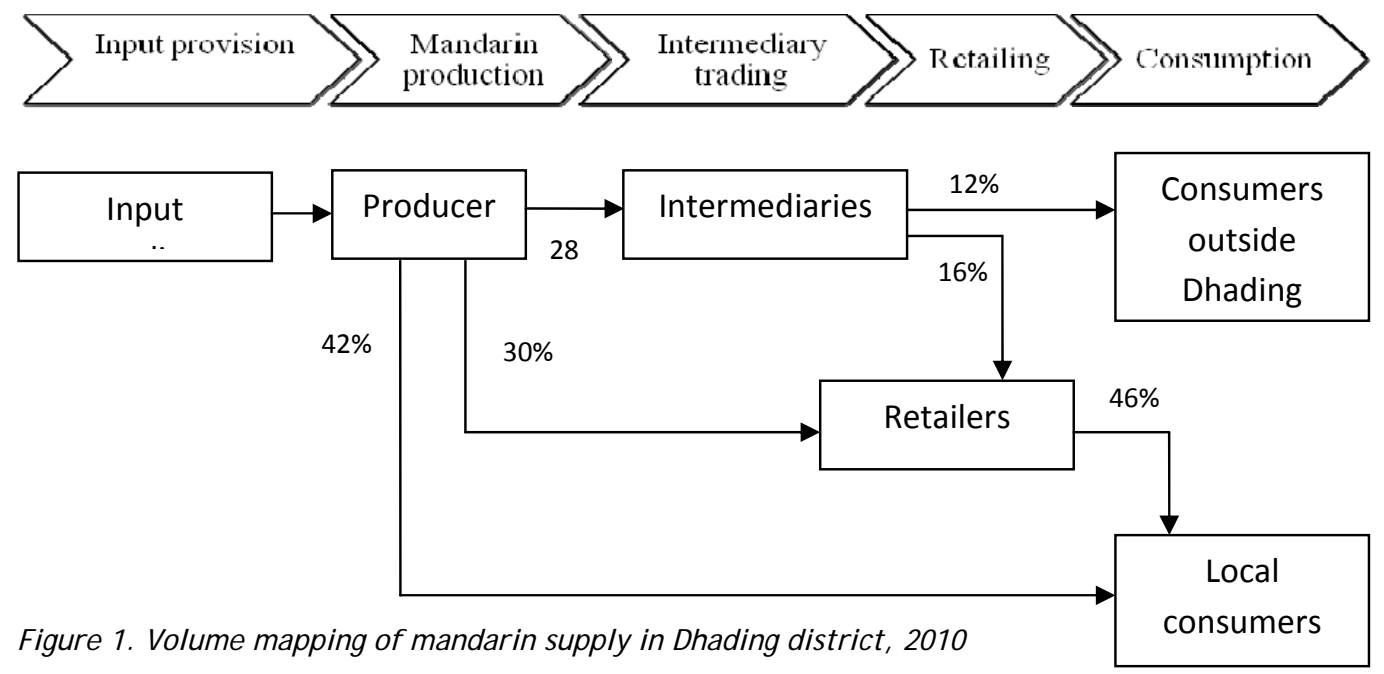

\section{VALUE CHAIN MAP}

Figure 2 illustrates the existing value chain map of mandarin in Dhading district which was explored during the study.

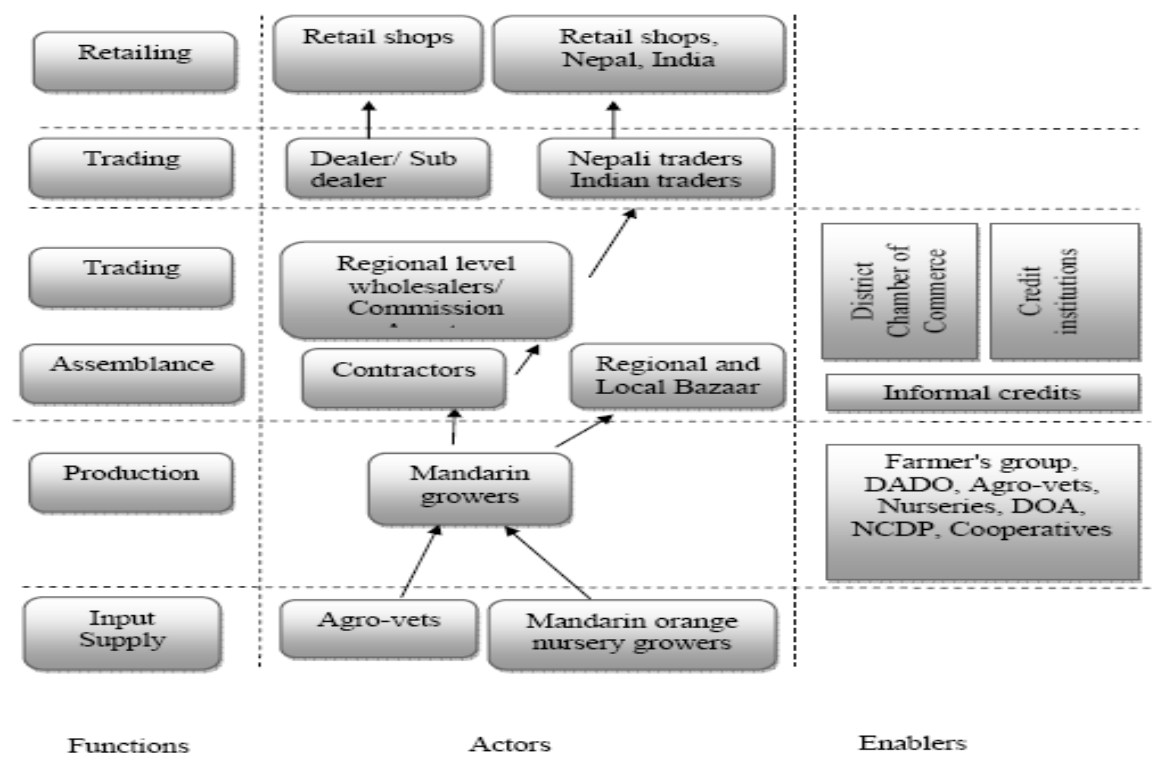

Figure 2. Value chain map of mandarin in Dhading district, 2010 
As seen in the figure, value chain map of Dhading district comprises of whole range of actors right from the input suppliers (agrovets and nurseries) to the ultimate consumers. Input suppliers were supplying the necessary inputs to the mandarin producers. Mandarin producers were involved in selling the produce of their orchards on contract basis to the contractors and also direct selling to the consumer. Mainly contractors and traders were found contracting the fruit orchards, harvesting of fruits, transporting and assembling the produce at the nearest road head, storing, packaging, transporting and selling to wholesale market. From there, mandarin oranges were sold to local traders and retailers and then finally reached to the consumers within and outside the district. But, the important part of the value chain, i.e. processing, was found missing in the entire value chain of mandarin in Dhading district.

MARKETING COST, PRICE SPREAD, MARGIN, MARKETING EFFICIENCY AND PRODUCER'S SHARE Figure 3 illustrates the summary of costs, margin, marketing efficiency and producer's share on consumer's rupee (NRs) per $\mathrm{kg}$ of mandarin in the mandarin value chain.

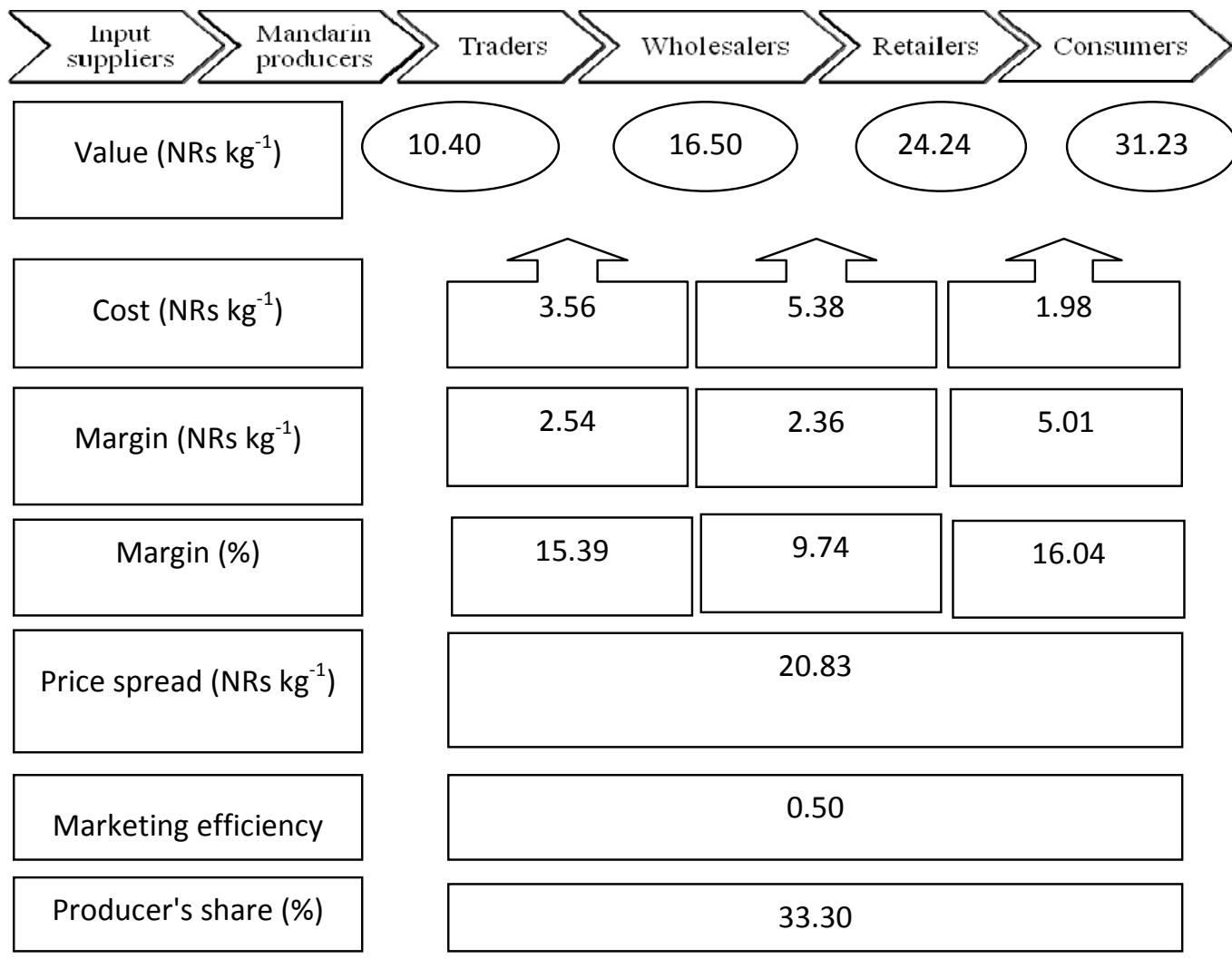

Figure 3. Marketing cost, margin, price spread, marketing efficiency and producer's share in the core process of mandarin value chain

$-118-$ 
The average farm gate price per $\mathrm{kg}$ of mandarin was NRs 10.40. The average selling price of traders and wholesalers was found to be NRs 16.50 and NRs 24.24 respectively. The average retail price was NRs 31.23 . The price spread was NRs 20.83 per $\mathrm{kg}$. In the study it was found that the retailers were having the highest margin (NRs 5.01) among the actors of mandarin value chain in Dhading district. The marketing efficiency of this chain was 0.50 . Similarly, the producer's share on consumer NRs in this chain was 33.30 .

\section{CONCLUSION}

Marketing of unprocessed mandarin was dominant in the mandarin value chain of the Dhading district which indicates lack of processed products. Gross margin and high B/C ratio received by the mandarin growers showed that the mandarin farming is a profitable business. While looking at the margin of intermediaries and retailers, their function in the mandarin value chain is always profitable because the downward swing of the market price never made their earnings negative. The retailers earned the biggest margin than others. It was one of the reasons for high price for consumer. The contractors were the main intermediary actors in the mandarin market chain of Dhading district. They were the main actor for inter-regional distribution of mandarin fruit.

\section{ACKNOWLEDGEMENT}

The authors express their sincere thanks to the research fund of NARDF for the financial support for this project. Kind responses from all the respondents, Research Directorate of Institute of Agriculture and Animal Sciences (IAAS), Rampur, Chitwan and colleagues are highly acknowledged.

\section{LITERATURE CITED}

ABPSD. 2014. Statistical Information on Nepalese Agriculture. Ministry of Agriculture and Cooperatives, Agri-Business Promotion and Statistics Division, Singh Durbar, Kathmandu, Nepal. pp. 67-68.

CBS. 2010. Statistical pocket book of Nepal, 2010. Government of Nepal, National Planning Commission Secretariat, Central Bureau of Statistics, Ramshahpath, Thapathali, Kathmandu, Nepal. 210p.

Gupta, G.S. and P.S. George. 1974. Profitability of Nagpur (Santara) oranges cultivation. Indian Journal of Agricultural Economics 29 (July-Sept.): 132-142.

Gurung, H.P. 1993. Horticulture Development in Nepal: Progress, Potential and Problems. In: Horticultural Development in the Hindu-Kush Himalayan Region (edited by Teaotia, S.S. ICIMOD). Oxford and IBH Publilshing Company Private Limited, 66 Janapath, New Delhi, India.

Shah, R. B. 1992. Trainers manual No. 16, Citrus fruit. Department of Agriculture, Central Agriculture Training Centre, Manpower Development Project, Kathmandu, Nepal.

Shrestha, B., P. P. Subedi and J. J. Thapa. 1998. Socio-economic factors affecting adoption of cellar store as a post-harvest technology for mandarin orange in the western hills of Nepal. LARC Working Paper No. 98/34.Lumle Agriculture Research Centre, Kaski, Nepal.

Tomiyashu, Y., S. K., Verma and D. B. Thapa. 1998. Citrus cultivation in Nepal. Horticulture Development Project Phase- II, HMG/JICA, Kirtipur, Nepal. (In Nepali). 120 p. 